SERGIY I. KOVALENKO

PhD (Technics), associate professor

National University "Odessa maritime academy"

Fanagoryiska str., 9, Izmail, Ukraine

E-mail: econ69@mail.ru

\title{
TRANSNATIONAL CLUSTERS SYSTEMS DEVELOPMENT PROSPECTS IN EUROPEAN ECONOMIC ENVIRONMENT
}

The presented work is dedicated to research of essence and internal links of transnational cluster systems as a factor contributing to competitiveness of the Black Sea Euroregion in view of advancing integration processes and necessity to increase part played by economy of peripheral territories within cross-border cooperation framework. Strategic priorities of network forms of cooperation within the context of the EU cross-border cooperation policy are identified. Advantages and parameters of cross-border industrial quasi-integration are explained in view of prospects of Ukraine entry into the EU. This work is dedicated to exploration of main features inherent to meso-level of international integration formations representing network structures in intra-branch and inter-branch cooperation in the form of cross-border cluster systems encompassing macro-levels and micro-level of integration of national economy of multiple states. Possibilities of theory synthesis of international economic integration and cluster concept in economic area virtualization environment are revealed. Cluster approach is proved to be the most efficient mechanism to develop cross-border economic relations and represents, finally, a meso-level of competitive international integration systems and mandatory condition of quality advance for Ukrainian European integration.

In the article it is stated that cross-border cluster unities in accordance with the worldwide experience become new forms of innovative development of the European regions with the involvement of Ukraine. The essence and inner interrelations of cross-border network cluster is investigated as the growth factor of the European region competitiveness under the conditions of intensifying the integration processes and the necessity of enhancement of the role of periphery regions' economy in the framework of cross-border cooperation. Within the context of European Union regional politics the strategic priorities of the spatial development of the European regions are stated on the basis of self-organization of "hybrid" network quasi integration institutions. Their role in the competitive recovery of the European regions in the light of Ukrainian perspectives of joining European Union is investigated.

Keywords: transnational cluster system, European integration, European region, innovations, efficiency, competitiveness.

КОВАЛЕНКО С.I.

кандидат екон. наук, дои.

Наиіональний університет "Одеська морська академія", Дунайський інститут вул. Фанагорийська 9, м. Ізмайл, Одеська обл., Украӥна, 68607

E-mail:econ69@mail.ru

\section{ПЕРСПЕКТИВИ РОЗВИТКУ ТРАНСНАЦОНАЛЬНИХ КЛАСТЕРНИХ СИСТЕМ В ЕВРОПЕЙСЬКОМУ ЕКОНОМІЧНОМУ ПРОСТОРІ}

Досліджено сутність і внутрішні взаємозв'язки транснаціональних кластерних систем як чинника зростання конкурентоспроможності Чорноморського єврорегіону в умовах посилення інтеграційних процесів $i$ необхідності підвищення ролі економіки периферійних територій в рамках транскордонного співробітництва. Визначено стратегічні пріоритети просторового розвитку мережевих форм транскордонної кооперації в контексті транскордонної політики Євросоюзу. Обгрунтовано переваги та параметри ефективності кластерних форм транскордонної промислової квазіінтеграџії в світлі перспектив вступу Украӥни в СС.

Ключові слова: транснаціональна кластерна система, євроінтеграція, єврорегіон, інновації, ефективність, конкурентоспроможність.

Introduction. For modern Ukraine problematics' urgency of transnational business systems development is directly related with demand for cross-border cooperation activation between adjacent regions and states, which formed a single people economy complex previously and became depressive regions after economic links collapsed. In terms of worldwide integration and globalization it leads imminently to competitiveness loss and decrease of quality of life and living standards of population.

Nowadays, euroregional cooperation development is of utmost persistency in a context of contemporary geopolitical processes. Ukrainian advance towards European integration and process of its admittance among European partners required coordinated efforts in cooperation development with EU member states - at the first turn - states with common borders with Ukraine.

Euroregional cooperation is characterized by higher grade of cooperating structures institutionalization 
and is a catalyst of European integration processes both at regional and national levels within an individual state. Major objective of euroregional cooperation, as of cross-border cooperation, lies in smoothening of state border functions and drawing together adjacent regions in economic, social and cultural aspects by means of leveling regional disparities and enhancing social and economic development of these territories. Euroregional cooperation is an important instrument of development of territories adjacent to borders, their competitiveness improvement, formation of growth centers using advantages of shared territory and cooperation as well, as an important component of European integration process [1, p. 6]. This provision is declared in National Regional Development Strategy for the period until 2020.

Implementation of newer marketing mechanisms enabling to improve regional competitiveness at European market with developing newer technological paradigm is possible basing on flexible forms of cross-border cooperation, coordination and integration of common activities among business entities operating in euroregions. As regards Ukraine, in particular, the competitiveness improvement problem at the global market is of utmost urgency [2, p. 17].

Formulation of the problem. The major objective of the proposed work consists in exploration of economic development priorities of euroregions where Ukraine is involved in terms of expanding EU by means of cross-border cluster systems generation being the institutions of networked industrial integrations becoming poles of economic growth and competitiveness for depressive peripheral territories at the European market.

Experience of advanced states worldwide indicates both efficiency and imminent generation of cross border cluster systems (CBCS), which, in situation of globalization, become centers of innovative euroregional economic advance and, consequently, "safety zones". Nowadays, from the author's point of view, there is a persistent urgent problem of unified CBCS generation, implementation and development mechanisms development. Therefore, implementation of regional economy upgrade basing on cross-border clustering requires new strategy development including detailed mechanism of cluster corporation forming and governmental support at both border sides relatively to modern conditions in Ukraine. The EU expansion in the context of structural priorities transformation and economic globalization requires search newer approaches to adapt cross-border regions to newer challenges, particularly in their competitiveness improvement.

Analysis of recent research and publications. Cluster approach in economy structuring, elaboration regional economic strategy and competitiveness improvement is commonly recognized among the advanced states. Since 1980s multiple researches were carried on and substantial number of works were published rising the questions of business entities' competitiveness in view of regional business climate and environment. An idea stating that national economy success depends, finally, on locally concentrated specialized branches' (industrial districts) development level was noted more than a century ago in works by Alphred Marshall (1890). He was the first who explored synergy effect gained with business entities' merging and specialization improvement. Alphred Marshall was one of the first who described advantages and proved feasibility of cluster theory as far back, as in the end of the $19^{\text {th }}$ century [3, p. 127].

Michael Porter in his work "Nations Competitive Advantages" has drawn to a conclusion, as below, “... transition economy developing the investment policy should strive to develop mutually dependent industrial clusters encompassing basic and supporting branches" [4]. The approach to regional competitiveness evaluation may be defined basing on the concept of total national competitiveness concept, as proposed by Michael Porter [5].

Researches carried on by J. Schumpeter, C. Erroy, P. Nelson and S. Winter consider problems rising with market structure modernization and competitive development as factors contributing to economic systems innovative activities improvement. They explore market participants integration mechanisms, newer innovative structures formation aimed to generate innovations in manufacturing, technology and organization. Essential contribution into solution of this problem was made by institutionalism representatives, such as O. Williamson [6], R. Coase [7], W. Nordhause, F. Heieck, in their works, describing following aspects,

1) Attention drawn to information drawbacks preventing mutually beneficial activities, discrepancies between "obvious" (coded) i "latent" (tacit) knowledge;

2) Focusing on transaction expenditures influencing advantages of individual organizational forms. Modern literature defines territorial forms network industrial integration as including industrial districts, holdings, clusters, territorial manufacturing complexes, which, in their turn, encompass regions, technological platforms, etc. The "industrial district" term evolved, as the time ran, towards enhanced notable features transformation review carried on by A. Marshall, G. Becattini, O Williamson [6, p. 211].

Works by national economists, such as B.V. Burkinskiy, V. M. Heyets, M. I. Dolishniy, V. S. 
Kravtsiv, Yu. V. Makogon, S. I. Sokolenko, S. V. Filippova, etc., are dedicated to cross-border regionalism forms and instruments development problems on the basis of quasi-integration in newer technological paradigm developing conditions and newer challenges imposed by global instability. They review various aspects of innovative form of networked cooperation, including substantiated strategies of economic growth in view of European integration of Ukraine. Scientific works by the abovementioned persons outline theoretical and methodical aspects of competitive cluster development. Nevertheless, it should be noted that mechanism of cross-border clusters formation is still practically unexplored in Ukraine and requires to be researched. Academician V. M. Heyets notes lack of methodological approach to cluster formations economic efficiency evaluation for various branches of economy, especially for development potential of regional formations as structurally integrated and unique territorial and administrative units.

The unsolved aspects of the problem. "Expenditures - Output" model methodology was applied for analysis of inter-branch relations within a cluster, specifying instruments for identification and development level evaluation of clusters and material of works by Ukrainian scientists, such as M. P. Voynarenko, V. I. Zakharchenko, N. A. Mikula, and foreign researchers W. Aizard, V. Leontyev, P. Neikampf. Researches and publications on cross-border industrial clustering are so far insufficient with Ukraine. They are, as a rule, of general or declarative nature. Furthermore, scientific theoretizing and practical steps are getting behind more and more obviously from those already being made by business and adjacent states in cluster formatting of economic space in euroregions.

Yet, so necessary theoretical foundation enabling to adapt Porter's cluster concept to domestic application was formed by researches in cross-border regional competition carried on in the Market Problems and Economic and Ecological Research Institute incorporated with National Academy of Sciences of Ukraine.

Problem of filling the gap between cluster theoretical model construction and demands, imposed by administrative bodies and business entities to put scientific foundation of adopted strategic decisions at meso-level, remains still unsolved. It means the urgent necessity to develop methodological instrumentarium of the model application at stage of cross-border industrial policy trends and ways identification, working out development strategies and programs for the Black Sea euroregions, and corporate competitive strategies. Furthermore, cluster theory is also being associated with corporation theory, innovative development theory, economic growth theory, etc. however, with all the available rather multiple researches dedicated to networked clusters, these structures still remain insufficiently studied both in terminology and contents aspects.

Results. Traditional power resources supply and cooperative relations between business entities of individual states will be supplemented by formation of transnational economic structures in various organizational and legal formats, such as financial and industrial groups, conglomerates, corporations, syndicates, joint ventures.

Regions adjacent to national borders and developing cross-border activities deserved their title of "European integration locomotives". They represent one of the ways integrating a state in global economy. The territories adjacent to border are the most reasonable to deploy free (special) economic zones, common innovations centers, technopolices and technoparks, business hubs involving foreign funding.

Specific conditions of newer economic system generation, determined by dual process of globalization and regionalization of worldwide economy, demands creation of more economically efficient territorial international formations, matching the modern productive forces development level. It leads to emergence of regional integrating reproduction complexes, encompassing significantly reproductive process within their own framework. In this view the enhanced attention is being paid to the item of clusters formation representing a group of business entities specializing in adjacent or associated branches closely cooperating with each other in the form of stable partnership on manufacturing, technological, scientific and innovative basis and therefore forming vertical and horizontal links at higher aggregation level to improve own competitiveness. Nowadays, clusters are extending their activity scales running beyond frames of individual states [8].

State administration bodies and business entities encourage foreign business entities involvement and exchange with foreign clusters to improve attractiveness of a certain region, or branch of economy. Growing number of public figures and business entities get aware that cluster strengthening and improvement of its feasibility and survivability in global competition between regions requires establishment of cross-border and transnational clusters with involvement of foreign corporations and universities as partners.

Special significance is being attained by cross-border and transnational clusters in innovations sphere. Their formation contributes favorably to:

- Development of close cooperation not only between business entities of various states, their 
suppliers and consumers of their production, but with knowledge institutions, including large research centers and universities working on international level;

- Creating competitive scientific and technological production capable to occupy and to keep positions on international market;

- Mastering certain skills in market researches enabling to estimate demand for newer products and relate it with global level;

- Establishing joint scientific centers to implement scientific developments;

- Encouraging scientific contacts, exchange, training and practicing;

- Joint working over international projects and programs.

In general, more opportunities (financial, administrative, etc.) appear to build up entire technological chain running from joint researches to production commercialization including its promotion at the market. Cross-border clusters formation in Common Economic Space (CES) is an urging objective, since it is cooperation of business entities within the cluster which enables to use jointly accumulated experience, survive in competition, meet global market demands for new products and technologies, and solve problems of technological uncertainty. The CES framework succeeded to preserve common transport, communications, power-generating and some other systems, which may work efficiently only if operated in joint mode. Pre-conditions of cross-border formation within the CES are caused by multiple factors which may be grouped into categories, as follow,

- Political factors: customs union establishment and adopting a solution to implement "four freedoms" (free circulation of goods, services, funding and labor); mutually agreed policy in macroeconomic and currency spheres; unified trading policy; cancellation of anti-dumping and other protective measures; developed international relations and membership in international organizations;

- Institutional factors: establishment of supra-national governing institutions; legal base formation facilitating favorable conditions for investments and preserving access to existing sales market, using advantages of opened borders and common transport network, harmonizing technical and governing standards and regulations and other non-tariff barriers; providing non-discriminated equal access to natural resources, including power-generating, as productive factors;

- Economic factors: positive dynamic of CES states economic development; increase in gross internal product (GIP); high demand level; available labor resources, raw materials and assembly parts; favorable investments climate; preferential taxation in innovations; developed transport infrastructure;

- Technological factors: available new technologies in industrial sphere; law governing spheres of technological and innovative development; increased potential demand for technologies and innovations; experience in cooperation and joint funding of scientific researches;

- Social and cultural factors: generation of standard databases and stimulation of data exchange; shared basic values and tendencies in lifestyle.

Potential possibilities to generate transnational clusters within the CES are available with various branches of economy, such as biotechnologies, pharmacy, chemical industry, machinery building, IT. Cluster formation requires system generation with prompt cooperation between government bodies, business entities, science and education. Coordination of fundamental scientific research, formation of common scientific and educational infrastructure within the CES states, mutual validity admittance of documents issuable in scientific and educational spheres, implementation of joint initiative in breakout sectors are also of utmost significance.

As defined, cross-border clusters encompass adjacent territories of neighboring states with institutions and business entities residing at both sides of the border. Therefore, cross-border clusters may be defined as groups of independent corporations and associated institutions which are:

1) Geographically concentrated in cross-border region;

2) Cooperate and compete;

3) Specialize in various branches;

4) Linked with common technologies and skills and supplement each other, finally, enabling them to obtain synergy and network effects, knowledge and skills exchange.

Specific feature of cross-border cluster consists in their participants habitation in different taxation, customs, legal environments. Yet they are able to have joint ventures and organizations, use common infrastructure and operate, primarily, at cross-border markets.

At the same time, Ukrainian economy may get benefits not only from creation of cross-border clusters to strengthen competitiveness of territories adjacent to borders due to intense resources, technologies (both manufacturing and administrative), "know how" exchange, unique business models implementation, common data space establishment, etc. Participation in such structures underlies a foundation for a prospect 
for Ukraine to gain deserved positions in global economic system.

Transnational cluster systems functioning should be aimed to create positive effects both at euroregional and national. Such effects may be divided into several groups, as described below,

1. Social effects. - They display, primarily, in creation new jobs, population income increase, improving employees' education level as a response to demand for qualified labor resources imposed by cluster participants.

2. Economic effects. - They include cost-saving from scope effect, access to advanced technologies and easier technologies transfer with consequent productivity increase due to involvement of innovative methods. 3. Fiscal effects. - They consist in budget income part increase due to expanded taxation base, possibilities to obtain donations from national programs in supporting priority trends in economic development. Successful cluster may consequently provide foreign investments into cross-border regional economy.

4. Reputation (image) effect - It is expressed in gradually improved recognition of a cluster and euroregion both at transnational and international markets.

The author proposes to apply a group of indicators, as described below, to evaluate positive effects from transnational cluster activities within a particular euroregion,

- Cluster share increase in total production output at transnational and international markets;

- Cluster share increase in national export;

- Cluster participants quantity increase;

- Investments increase accumulated with the cluster;

- Increase in number of employees within the cluster forming branch;

- Decrease

- evaluation based on income ratio obtained from cluster participants to investments into creation of the cluster.

- The enlisted indicators in wear and tear of fixed assets;

- Increase in balance profit of enterprises involved into cluster;

Multiplicative effect are proposed for transnational cluster successful development review, as may be required to establish a balanced euroregional economic.

Odessa Region is a single among regions adjacent to sea involved into activity of the "Lower Danube" euroregion and takes an active part in five European cross-border institutions, such as Euroregional Assembly, European regions adjacent to borders association, Community of Danube States, European Marine Regions Conference, European Wine-Producing Regions Assembly. At the beginning of the $21^{\text {st }}$ Century the Black Sea Region gains a strategic significance contributed by the NATO and EU expansion, strengthening of Russian, Turkish and Chinese factors, implementation of European neighborhood policy for majority of European states, Romanian and Bulgarian joining the EU, development of trading relation between states situated along trade routes between Europe and Asia. All these factors contributed to formation of a concept of Wider Black Sea Region.

To date, a project is being implemented to create "the Black Sea Euroregion" within the framework of European Neighboring and Partnership Program launched in 2007 involving Bulgaria, Greece, Romania, Ukraine, Turkey, Russian Federation, Georgia, Dniester Region of Moldova. With increasing interest to cross-border cooperation from the EU party the "Black Sea" euroregion may become an important tool for Ukrainian advance towards European integration. It might be feasible to create a maritime cross-border cluster within the "Black Sea" euroregion encompassing coastal regions of various states adjacent to the Black Sea to organize activity of business entities aiming to achieve a particular economic target.

The term "maritime cluster" means a grouping of companies, scientific and research institutes and educational establishments (universities, specialized schools, etc.) sometimes supported by national or local authorities cooperating to implement certain technical innovations to improve maritime industry activity. This term in interpreted in extended sense in Netherlands, Norway, Italy and means a complex of maritime activities which are linked with each other and interact, e.g. seafaring, ports operations, shipbuilding and ship repairs, fishing, marine tourism, offshore entities, etc.

Logistical network operation within the framework of cross-border maritime cluster may contribute to optimum organization of transport and manufacturing complex on territorial basis. Sphere of economic activities in ports expanded beyond territorial borders and was transferred to auxiliary objects beyond them according to complex supply system due to fundamental alterations in global economy, technology and society. Such an approach leads to port logistical networks formation encompassing various transport nodes, such as specialized ports, terminals, storages and workshops, industrial objects with their activities sensitive to cargo operations in large ports. Special attention should be paid to developing an innovative model of cross-border cooperation, which provides for resources concentration in regions adjacent to borders to carry 
on fundamental and applicable researches to increase their scientific, technological and productive potential and application of programmed targeted approach to innovative projects aimed to development of the Black Sea coastal euroregion [8, p.29].

Creation and operation of cross-border maritime cluster at the Black Sea coastal region may contribute beneficially to economic cooperation between the involved states. As for Ukraine, creation of such cluster may influence on ports' integration into regional logistical network and Ukrainian industry may integrate into existing international manufacturing chains, improving business activity level, its innovative and competitive capabilities.

It may be proposed to establish cluster systems development centers within the structure of regional Commerce and Industry Chambers as a driving element in implementing cluster strategy at the regional level, applying such advanced technologies, as leasing, franchising, outsourcing, subcontracting, and other to solve tasks, as follows,

- Cooperation coordination between participants in regional cluster initiatives;

- Assistance in attracting foreign investments and involving new participants in regional cluster initiatives;

- Prompt consultative support services rendered to projects and investors;

- Cluster projects implementation coordination with national administrative bodies and foreign partners at all levels;

- Assistance in labor resources supply to regional clusters;

- Enhancing competence levels of parties involved into regional cluster initiatives.

Following trends may be mentioned as priorities in high-tech cross-border clusters competitiveness improvement:

- Opportunities research for applying special cooperation modes by means of euroregions formation;

- Cooperation development between commercial and educational structures in personnel training in required qualifications;

- Cooperation enhancing between cross-border cluster participants, including "science - business" schemes, especially in scientific and research and production promotion at the market facilitating local production expansion to external lines and attraction of more skilled competitors, suppliers and consumers;

- Applying adequate methods of motivation for different professional groups at internal corporate levels guaranteeing manufacturing processes quality improvement and high-tech production output;

- Creation of manufacturing infrastructure necessary for small and medium business demanding scientific component (production areas, access to funding, etc.);

- Development of associated economic sectors in regions adjacent to borders, particularly in accessories manufacturing and high-tech industry servicing;

- Creation of joint innovative, technological, marketing and logistical centers;

- Improvements in institutional environment (legal, certifying and others, improvement of standards system) with mandatory simultaneous clarification of varying administration influence on efficient operation of science-consuming business.

Ukrainian integration into EU, as a process, requires from business entities to establish contacts with various trans-European networks (information and telecommunications, innovative, consulting, etc.) enabling to apply promptly results of scientific research, encouraging innovations implementation and labor resources development and scientific and research potential, produce positive effect upon regional political, social, economic and cultural development.

Modern post-industrial paradigm of euroregional development transforms essentially priority of deployment factor, which changes functions of peripheral territory. It turns gradually from physical basis (place of material resources location) into spatial environment for development of human capital, innovations and euroregion independent development [9, p. 36].

Newer post-modern reality consists in combination of post-industrial manufacturing with networked structure of economic space. It supposes institutions transplantation by means of hybrid network clusters self-organization at both sides of national borders becoming a factor for integration and free funds circulation in euroregions. Competitiveness with such newer mode is determined by innovations implementation rate and capability to continuous renovation.

Modern theoretical economics supplements an "integration / disintegration" dichotomy with one another "quasi-integration" category, and "corporation - market" dichotomy is expanded with "hybrid" category. Applying the assets control criterion quasi-integration may be defined as a process of establishing control over behavior of formally independent corporations without taking their assets under control [9]. 
Distinguishing specific feature of a cluster as a quasi-integration form is its geographical localization, displaying concentration of mutually related companies, specialized suppliers and supporting organizations within restricted territory, which compete and at the same time cooperate with each other in their common activities. A number of experts regard clusters as a practically sole real source of investments and innovations. Yet clusters still remain a kind of theoretical construction with none practical sensible features and positive externalities. However, these quasi-integration forms may become a main driving force of innovation in forthcoming future.

\section{Conclusions and prospects of further developments.}

1. Industrial corporate networks become major objects of economic management in post-industrial economic system. They transform into transnational cluster system under the influence of globalization and internationalization processes. Network clusters are the agents of technological alterations, as they incorporate organizations carrying on scientific and research works as well, as their commercialization and implementation into manufacturing activities within the framework of a particular cluster.

2. Actual opportunities with the Black Sea euroregion opening up with cross-border clusters creation are, as follows,

- Euroregional economic specialization development and increase in competitiveness;

- Creation of favorable conditions for economic activities and positive investment image for the euroregion;

- Economic diversification and emergence of "point of growth" with maximum concentration of labor, material and innovative resources;

- Efficient development of small and medium business;

- Emergence of condition for more efficient utilization of human potential;

- Development of tourism and associated entertainment business

- Implementation of euroregional development processes and local authorities' initiatives in priority directions.

3. Nowadays a persistent demand is to develop and implement cross-border development strategy for euroregions in view of European experience in generating trans-regional strategies. It should be noted that an object of such a strategy is a steady social and economic development of euroregional system encompassing its human, natural, resources potential and institutional environment.

4. Ukrainian striving into the EU requires to consolidate cross-border cooperation experience as a preliminary and supplementing stage of integration in regional dimension. Theoretical and methodological foundation of cooperation and newer forms and mechanism for its implementation in view of transnational cluster systems should be developed to form an integrated, consistent and efficient policy of cross-border cooperation development in Ukraine.

\section{REFERENCES}

1. Assembly of European Regions (1996). Declaration concerning regionalism in Europe. Strasbourg: Secretariat General Immeuble Europe.

2. Europe Innovation Cluster Mapping Project (January 2008). Cluster policy in Europe. Oxford Research AS.

3. Marshall A. (1928). Elements of Economics of Industry Being the First Volume of Elements of Economics. London.

4. Porter M. E. (1998). Clusters and competition: new agendas for companies, governments, and institutions. MA: Harvard Business School Press.

5. Porter M. (1990). The Competitiveness Advantage of Nations. London: Macmillan,.

6. Williamson O. (1985). The Economic Institutions of Capitalism. New York: Free Press.

7. Coase R. G. (1994). Nature of the Firm. Lessons business organization. St. Petersburg, Lenizdat.

8. Armstrong H.W. (1995). The Role and Evolution of European Community Regional Policy. B. Jones, M. Keating (Eds.). The European Union and the Regions. Oxford: Clarindon press, 23-62.

9. Rekord S.I. (2012). Metodologiya razvitiya klasternyh sistem kak mezourovnya mezhdunarodnoj ehkonomicheskoj integracii. SPb. : Izd-vo SPb GUEHF. 